\title{
APPRAISAL OF KEY PERFORMANCE INDICATORS ON ROAD INFRASTRUCTURE FINANCED BY PUBLIC-PRIVATE PARTNERSHIP IN NIGERIA
}

\author{
T. E. Oyigbo ${ }^{1, *}$ and 0. 0. Ugwu ${ }^{2}$ \\ 1, Civil ENGineERING DEPARTMENT, UNiversity OF NigERIA NSUKKA, ENUGU STATE, NIGERIA. \\ 2, Department of Civil EngineEring, Federal Univ. Ndufu-Alike IKWo, AbakaliKi, Ebonyi State, NigERIA. \\ E-mail addresses:10yigbo2000@yahoo.com, ${ }^{2}$ onuegbu.ugwu@funai.edu.ng
}

\begin{abstract}
As Public-Private Partnerships (PPPs) are being practiced in most parts of the world, the need to adopt a system mechanism to evaluate the performance is imperative. The paper evaluates sustainable key performance indicators (KPIs) with a view to appreciating times of improved performance or otherwise. Eleven performance indicators for PPP in Nigeria were identified and ranked on a scale of 1 to 5 as follows: It indicates that increased road network size with mean score of 4.65 is the highest rated key performance indicator in a PPP project. Other important factors include Increased asset value, Increased road usage, Reduced road accident, Reduced travel time, Reduced user cost, Reduced maintenance cost, Reduced public sector administration costs, with mean scores of 4.14, 3.99, 3.75, 3.65, 3.59, 3.53, 3.39 respectively. The research alternative hypothesis is "Increased road network size is the most accepted performance indicator for evaluating progress of PPP financed projects". Chi-Square was adapted to test the hypothesis and it rejected the null hypothesis and accepted the alternative hypothesis. It follows that increased road network size is the most rated performance indicator in evaluating PPP projects. Good service outcome is the target of any PPP project and its achievement attaches value for money (VFM) and general confident to the project.
\end{abstract}

Keywords: Public-Private Partnerships (PPPs), Key performance indicators (KPIs), service outcome, value for money (VFM).

\section{INTRODUCTION}

1.1 Background of the Study

Many institutions carry out infrastructure development, through PPP, but measurable indicators to success or otherwise do not exist. According to Li [1], Public-Private Partnership entails an arrangement between government and private sector entities for providing public infrastructure, community facilities and related services. Such partnerships, he observed, are characterized by the sharing of investment risk, responsibility and reward between the partners. Li's definition is in line with the explanations given to the subject matter by the Canadian Council for Public and Private Partnership Report [46] that sees PublicPrivate Partnership as a co-operative venture where there is an allocation of the risk inherent in the provision of public service between the public and private sectors. Despite the interest in PPP, there is need for more systematic and in-depth research to examine the measures that enhance Value for Money (VFM) in PPP projects [2]. The Canadian Council for Public Private Partnerships [47] defines PPP as "a cooperative venture between the public and private sectors, built on the expertise of each partner that best meets clearly defined public needs through the appropriate allocation of resources, risks and rewards." PPPs have been practiced worldwide in both developed and developing countries with multiple objectives including promoting infrastructure development, reducing costs, increasing construction and operation efficiencies, and improving service quality by incorporating the private sectors' knowledge, expertise, and capital.

In this research, a series of problems have attracted researchers' interests. To date, much of the extant literature has been restricted to examining one of the following four aspects of PPPs:

i. Providing an explanation for the rise in their popularity with government and some problem conclusions [3-8, 48].

ii. Discussing the outcomes of PPP projects based on case studies [9-12].

iii. Suggestions on how to make decisions to implement a PPP project mainly including tender

\footnotetext{
* Corresponding author tel: $+234-703-636-2852$
} 
selection and future risks analysis [3-9, 13-22], 49].

iv Examining the criteria that make for a successful PPP project $[23,24]$.

Noble and Jones [25], concluded that lack of micromanagement analysis and stage-specific analysis weretwo critical problems identified in their research. Kagioglou et al. [26] presented a framework, which ensured that effective strategies were deployed to form the performance management system that construction organizations can adopt. Bititchi, et al. [27] explained the distinction between performance management and measurement as follows: Performance management is the process of identifying, measuring, managing, and developing the performance of resources in a system. Performance measurement, on the other hand, is the ongoing process of evaluating resources in a system.

Key performance indicators (KPIs) are specific milestones or components of performance measures that serve as gauge to indicate progress toward the eventual achievement of a target. Performance measures are the broad classifications of desired outcomes required of the concessionaires. Contractual goals and statements of increasing and decreasing specifics, ensuring a specific, establishing a specific, or implementing a specific for a project, reflect (KPIs). Key performance indicators typically include, but are not limited to, elements such as project benchmarks, targets, milestone dates, numbers, percentages, variances, distributions, rates, time, cost, indexes, ratios, survey data, and report data. The overall purpose of this paper is to describe the role of performance indicators in modern road asset management. More specifically, the basic objectives of performance indicators are identified, the importance of stakeholder involvement and needs are discussed as well as the need to achieve balance efficiency and relation to transportation values in using performance indicators.

A 'Key Performance Indicator' (KPI) or performance 'measure'/'indicator' according to Wall and Martin [28], is a type of performance measure used to evaluate success of delivery of services and other endeavours in both public and private organizations. Pallister and Isaacs [29] assert that KPI management was integral to long-term organizational success and suggested that indicators should be used to identify both strengths and weaknesses. Operational indicators relate to the success and profitability of the supply of services including productivity and output. This differs from a view offered by Cox, et al [30] who opined that KPIs are used to assess task-based employee performance. For this research, however, KPIs are defined as indicators that are used to evaluate the achievement of intended VfM outcomes, and are used for comparing actual performance against specified targets in terms of establishing the effectiveness and efficiency of service delivery. Performance evaluation for this research is defined as a systematic (and continuous) process of gathering, monitoring and analyzing data against KPIs to determine how well the private partner is performing against its contractual obligations [31,32]. For public partner contract managers, evaluation includes preparing options that may be taken against under-performing service providers e.g. whether to apply penalties or abatement [33, 34].

Without making comparisons between baseline measures and actual performance, it would be impossible to determine how well or poorly a service provider is performing [35]. Full accountability of the private party to government is to be achieved through well-defined governance structures that include clarifying key roles and responsibilities, risk and evaluation frameworks [36, 37]. A specification of flexible, measurable and practical standards should be put in place. These standards incorporate KPIs that are linked to incentives for meeting or exceeding targets [36]. Lee and Fisher [38] asserted that there was a strong correlation between the attainment of organizational objectives and effective performance management. Adhering to above statement may appear simple; however, programs (or in this case the achievement of PPP objectives) can fail due to poorly defined KPIs [39]. KPIs should not be vague to avoid different interpretations [40]. This can be exacerbated by changes of staff [41] and differing perceptions or interpretations of performance outcomes. KPIs can be used as a mechanism to calculate the level of payment that will be made by the public partner to its private partner [42], commensurate with the operator's performance [43]. If the desired levels of performance are not achieved, a warning notice or penalty points may be issued, Mandri-Perrott added. This research presents performance measurement methods for partnerships on infrastructure based on the submissions of professionals who have engaged in PPP projects.

\subsection{Statement of Problem}

Achievement of the goal for infrastructure development and maintenance demands empirical record of progress, which does not exist. Currently, measurable indicators to highlight the extent of success in PPP investment have not been properly identified. A major task before relevant organizations of government, say Infrastructure Concession Regulatory 
Commission (ICRC), is to ensure that stake holders in the sector develop and adopt empirical methods of measuring progress. Inadequate research reports may have been responsible for lack of awareness on measurable performance indicators.

\subsection{Aim of Study}

The study was set to appraise key performance indicators on road infrastructure financed by publicprivate partnership in Nigeria. Personal experience of the researcher in highway engineering was the steering spirit. Money was being sunk into the road sector without widely accepted indicators to measure progress.

\subsection{Objective of Study}

The study was guided by the following objectives:-

i. To identify the key performance indicators on road infrastructure financed by public-private partnership in Nigeria;

ii. To establish how stakeholders in the road sector rank the various indicators in evaluating operational performance.

\subsection{Research Questions}

i. Are there measurable indicators that can be used to evaluate performance of PPP financed projects in Nigeria?

ii. What are their degrees of acceptance as parameters for measuring various components of PPP projects?

\subsection{Research Hypothesis}

The hypothesis formulated and tested is:

i. Increased road network size is the most accepted performance indicator for evaluating progress of PPP financed projects.

\subsection{Limitation of the Study}

Variation in Stakeholders' views of degree of agreement on Key performance indicators was not accommodated in the current study.

\subsection{Recommendation for Further Studies}

Online-real time questionnaires administration system to be formulated on Microsoft workbook to enable regular update of stakeholders' views. Variation in Stakeholders' views of degree of agreement on Key performance indicators to be included in subsequent studies. In tabular form and using similar matrices, compare and contrast KPI with other methods for measuring performance in projects. Also, discuss the reason(s) KPI is better and should be utilized in PPP projects.

\section{MATERIALS AND METHODS}

\subsection{Research Design}

This study adopted the survey and descriptive research design.

\subsection{Source of Data}

Data for this research are from primary and secondary sources.

\subsubsection{Primary Sources}

Primary data was obtained from questionnaires administered on the selected group, interviews and observations. Practical questions were presented to relevant categories of individuals involved in PPP arrangement.

\subsubsection{Secondary Sources}

Literature review of content of newspapers, magazines, seminars and symposia by known academicians formed the secondary data for the research.

\subsection{Population of Study}

The population of the research was all Nigerian adults that use the road. The population is estimated to be $50 \%$ of the current Nigerian population. Reference to the 2006 census and an annual population growth rate of $2.67 \%, 191,852,961$ is the current population of Nigeria. The research population, $50 \%$ of the current Nigerian population, is $95,926,481$. The population was segmented into End-users, Concessionaires, Consultants and Public Sector personnel for convenience of analysis.

\subsection{Determination of Sample Size}

Due to the large number of population, a sampling technique is needed. The sample of this research is calculated using Taro Yamane formula with 95\% confidence level. The calculation formula of Taro Yamane is presented as follows.

$$
N=\frac{n}{1+n e^{2}}
$$

In (1), $n$ is the sample size, $N$ is the population of the study, e is the level of significance or (limit of tolerable error) $=0.05$. So from (1) and for $n=95,926,481, N=$ 400.

\subsection{Instrument of Data Collection}

The principal instrument used for data collection in the study was structured questionnaires administered on respondents. The questionnaires were distributed personally to the various respondents thereby giving 
the researcher the opportunity of making first hand observation and independent judgment.

\subsection{Sampling Techniques}

Simple random sampling techniques was used for the study. The approach was a deliberate effort to ensure that all the elements of the population had equal chance of being selected.

\subsection{Validity of the Instrument}

To validate the instrument, professionals in the construction industry (e.g. in FERMA) were shown the draft questions for vetting. They ensured that the questions were appropriate and covered the objectives of the study. The ease of completing the questionnaires points at its validity. Approximately five minutes was used to complete one questionnaire.

\subsection{Structure of Respondents}

Target groups for the survey were selected based on some criteria as indicated on Table 1 . The sample size was fairly distributed among Public Institutions personnel, Consultants, Contractors/ Concessionaires and end-users as indicated on Table 2. The first part of the questionnaire contains questions on the demographic information of the respondents and questions about respondents' age, place of work and position in the place of work. The second part of the questionnaire has questions that appraise the performance indicators of PPP using a five-point Likert scales.

\subsection{Method of Data Analysis}

The method of analysis used in this research is the mean score ranking technique and standard deviation using Microsoft Excel 2007. Point scales were used to calculate the mean score for each response factor or option. The mean scores were then used to rank options in descending order or importance. The mean score for each factor or option was calculated by using the following formula [46]:

$$
\mathrm{MS}=\frac{\sum(f \times s)}{\mathrm{N}} \quad \text { and, }(1 \leq \mathrm{MS} \leq 5)
$$

Where $s$ is the score given to each factor by respondents, $f$ is the frequency of each rating for each factor or option and $\mathrm{N}$ is the Total number of responses for that factor or option.

The mean score is a weighted average for the responses received for each question. The mean scores were calculated by first multiplying the number of respondents by the weight of the response option to determine the weighted value. Total numbers of respondents were calculated for all rating options. The calculated weighted value is divided by the sum of all respondents, giving the mean. From the five-point Likert scale, formulas used to calculate sample standard deviation and mean are,

$$
\begin{gathered}
\text { Mean }=a+\frac{\sum \mathrm{fd}}{\sum \mathrm{f}} \\
\text { S.D }=\sqrt{\frac{\sum \mathrm{fd}^{2}}{\sum \mathrm{f}}-\left(\frac{\sum \mathrm{fd}}{\sum \mathrm{f}}\right)^{2}}
\end{gathered}
$$

In (3) and (4), $\Sigma$ is the Sum of enclosed items, $x$ is the Individual score, $a$ is the Mean of all scores, $f$ is the Frequency of scores, $d$ is the Difference between class mark and average mark $=\mathrm{x}$-a. Equations 2 and 3 give the same result of mean.

A hypothesis was set out for Chi-Square Goodness of Fit Test and the formula was adopted as shown in equation 5 .

$$
x^{2}=\sum_{i=1}^{k}(O i-E i)^{2} / E \mathrm{i}
$$

where $\mathrm{k}$ is the number of categories, or cells in the table; $\mathrm{O} i$ is the observed frequency in cell $i$; and Ei is the expected frequency in cell i.

\subsection{Template on Measurable Key Performance Indicators on Road Projects Financed by PPPS and Record of PPP Projects in Nigeria}

The researcher articulated materials and formed a table indicating measurable performance indicators for evaluating PPP projects. The result is from field experience and literature. Record of key PPP projects being undertaken in Nigeria was gotten.

Table 1: Target group and criteria for selection (Source: Analysis of Research Data)

\begin{tabular}{lll}
\hline S/No & Target group & Criteria for selection \\
\hline 1 & $\begin{array}{l}\text { Public Institutions/Bureau of Public } \\
\text { Procurement }\end{array}$ & They represent the interest of government in the PPP projects \\
2 & Consultants & $\begin{array}{l}\text { Consultants have the experience and offer expert advice in the } \\
\text { financing scheme. }\end{array}$ \\
3 & Contractors/Concessionaires & $\begin{array}{l}\text { This group, commonly referred to as SPV (Special Purpose } \\
\text { Vehicle) has the technical skill and finance. }\end{array}$ \\
4 & Ordinary citizen (End-users) & Ordinary citizens feel direct impact of the outcome of any PPP. \\
\hline
\end{tabular}


Table 2: Questionnaires administered (Source: Field

\begin{tabular}{lll}
\multicolumn{2}{c}{ survey, 2015) } \\
\hline S/No & Organizational & No of questionnaires \\
\hline 1 & Plassification & administered \\
2 & Consultants & 100 \\
3 & Concessionaires & 75 \\
4 & End users & 75 \\
\hline TOTAL & 150 \\
\hline
\end{tabular}

Table 3: Distribution of respondents indicating rate of return (Source: Field Survey, August 2015)

\begin{tabular}{clccc}
\hline S/no & Respondents & $\begin{array}{c}\text { Total } \\
\text { administered }\end{array}$ & $\begin{array}{c}\text { Total } \\
\text { returned }\end{array}$ & $\begin{array}{c}\% \\
\text { return }\end{array}$ \\
\hline 1 & Public Sector & 100 & 56 & 56 \\
2 & Consultants & 75 & 69 & 92 \\
3 & Concessionaires & 75 & 72 & 96 \\
4 & End users & 150 & 39 & 26 \\
& TOTAL & 400 & 236 & 59 \\
\hline
\end{tabular}

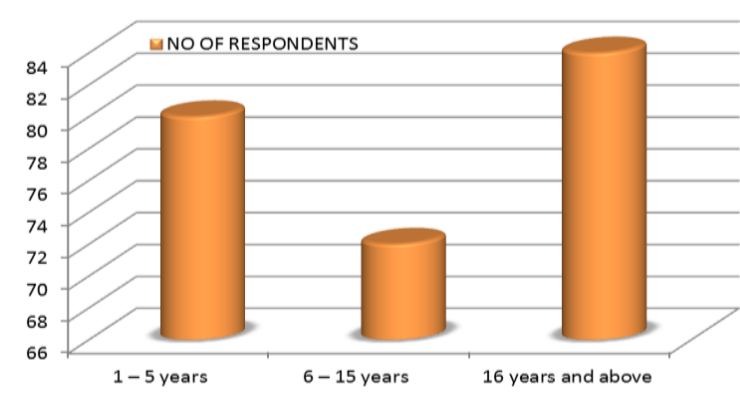

Figure 1: Distribution of respondents according to years of experience

Table 4: Distribution of respondents indicating position in the society

\begin{tabular}{llll}
\multicolumn{3}{c}{ in the society } \\
\hline \multirow{2}{*}{ S/NO } & $\begin{array}{l}\text { Position in the } \\
\text { society }\end{array}$ & $\begin{array}{l}\text { No of } \\
\text { respondents }\end{array}$ & $\begin{array}{l}\% \text { of } \\
\text { respondents }\end{array}$ \\
\hline 1 & Director & 56 & 24 \\
2 & Chief Engineer & 69 & 29 \\
3 & Site Engineers & 72 & 31 \\
4 & Non-Engineers & 39 & 17 \\
\hline
\end{tabular}

\section{RESULTS AND DISCUSSION}

From the 400 questionnaires used to generate field data, respondents from the public sector received 100 and returned 56 properly completed making $56 \%$ rate of return. Consultants retuned 69 out of 75 questionnaires administered on them resulting in $92 \%$ rate of return. The concessionaires received 75 questionnaires and returned 72 making the least rate of return of $96 \%$ probably for skepticism as to the real intention of the researcher. End users received the highest number of questionnaires of 150 and returned 39 in valid state yielding $26 \%$ rate of return. In all, 236 completed survey questionnaires were returned from the 400 questionnaires administered representing response rates of $59 \%$ as indicated on Table 3. Aibinu et al. [44] in accessing construction delays and their causative factors in Nigeria, made reference to the assertion by Moser and Kalton [45] that "the result of a survey could be considered as bias and little value if the return rate was lower than $30-40 \% "$. This assertion indicates that the response rate of $59 \%$ was adequate for the analysis. Respondents were asked to rate the factors according to a scale from 1 to 5 ( $1=$ strongly disagree and $5=$ strongly agree), a value above " 3 " and would represent agreement. The value " 3 " represents neutral or undecided.

\subsection{Demographic Characteristics of the Respondents}

The demographic information is presented under the following sub-sections; sector of interest, work experience and position held by respondents.

\subsubsection{Work Experience}

From the 236 respondents, respondents within 5 years of experience are 80 yielding 34\%. Respondents within the experience bracket of 6 and 15 years are 72 resulting in 31\%. Respondents with 16 or more years of experience are 84 making $36 \%$ as indicated on Figure 1. From the figure, it is evident that most of the respondents have working experience above 16 years, justifying input of advanced hands and higher validity.

\subsubsection{Position of Respondents}

Table 4, in terms of the Position of respondents, 56 respondents representing $24 \%$ are Directors, 69 respondents representing 29\% are Chief Engineers, 72 respondents representing $31 \%$ are Site and Pupil Engineers while 39respondents representing $17 \%$ are Non-engineers.

\subsection{Key Performance Indicators in A PPP Project}

Table 5 shows the mean values and the degree of agreement of key performance indicators in assessing a PPP project, as rated by respondents. It indicates that increased road network size with mean score of 4.65 is the highest rated key performance indicator in a PPP project.

Other important factors include Increased asset value, Increased road usage, Reduced road accident, Reduced travel time, Reduced user cost, Reduced maintenance cost, Reduced public sector administration costs, with mean scores of $4.14,3.99,3.75,3.65,3.59,3.53,3.39$ respectively. The degree of agreement of a given performance indicator is directly proportional to its Mean Score as indicated on Table 5. 


\subsection{Hypothesis Testing and Interpretation of Results}

\subsubsection{Statement of Research Hypothesis 1}

H0: Increased road network size is not the most accepted performance indicator for evaluating progress of PPP financed projects.

H1: Increased road network size is the most accepted performance indicator for evaluating progress of PPP financed projects.

While $\mathrm{H} 1$ is the research hypothesis, $\mathrm{H} 0$ is the null (nothing-is-going-on) hypothesis. Research Analysis was carried out using Chi-Square Test

$$
x^{2}=\sum_{i=1}^{k}(O i-E i)^{2} / E i=C h i-\text { Square equation }
$$

where: $\mathrm{Oi}$ is the observed frequency in cell I (frequency for each case) and Ei is the expected frequency in cell I (the average of the respondents that rated the scale $=$ $236 / 5=47.2$ )

Reference to Chi - Square Standard Table and Table 6, Degrees of freedom is 4, Critical Chi-Square value is 9.448 and Chi-Square test statistic value is 526.864 . The calculated $x^{2}>$ critical $x^{2}$ (from the Chi-Square table at $5 \%$ level of significance). The null hypothesis is rejected and the alternative hypothesis accepted. It follows that increased road network size is the most accepted performance indicator for evaluating progress of PPP financed projects.

\subsection{Template on reporting Key Performance Indicators on Road Development and Maintenance Activities}

The study of KPIs is targeted at assessing effectiveness and efficiency of projects. Critical success factors have been identified in various contexts. Most of these studies are too generic and pose a question of applicability on a specific industry such as construction. Table 6 is a template, developed by the researcher, which can be reviewed by stakeholders and used as a guide for performance assessment. It sets out a three-year test on identified performance indicators. There are units for measuring indicators of all aspects. On the aspect of road network sizes, six performance indicators with their units of estimation are set thus: $i$. length $(\mathrm{km})$, ii. paved $(\mathrm{km})$, iii. bridges, culverts (Number), iv. Tunnels (Number), vi. Right-of-way area (Hectare).

Table 5: Key performance indicators in a PPP project - Joint stakeholders' rating of degree of agreement yielded the mean scores.

APPRAISAL OF THE PERFORMANCE OF PPP

Please indicate scale 1-5, the extent of agreement of the following factors assessing the performance of PPP projects. 1- Strongly disagree, 2- Disagree, 3- Undecided, 4- Agree, 5- Strongly agree.

\begin{tabular}{llcccccccc}
\hline & $\begin{array}{l}\text { Please rate the key performance indicators in a PPP } \\
\text { project }\end{array}$ & 1 & 2 & 3 & 4 & 5 & Total & $\begin{array}{c}\text { Mean } \\
\text { Score }\end{array}$ & $\begin{array}{c}\text { Standard } \\
\text { Deviation }\end{array}$ \\
\hline 1 & Increased road network size & 0 & 12 & 16 & 14 & 194 & 236 & 4.65 & 0.817 \\
2 & Increased asset value & 4 & 20 & 30 & 68 & 114 & 236 & 4.14 & 1.041 \\
3 & Increased road usage & 22 & 16 & 20 & 62 & 116 & 236 & 3.99 & 1.299 \\
4 & Reduced road accident & 16 & 18 & 56 & 66 & 80 & 236 & 3.75 & 1.195 \\
5 & Reduced travel time & 32 & 18 & 34 & 68 & 84 & 236 & 3.65 & 1.380 \\
6 & Reduced user cost & 22 & 36 & 34 & 68 & 76 & 236 & 3.59 & 1.323 \\
7 & Reduced maintenance cost & 14 & 32 & 64 & 66 & 60 & 236 & 3.53 & 1.177 \\
8 & Reduced public sector administration costs & 18 & 60 & 30 & 68 & 60 & 236 & 3.39 & 1.309 \\
\hline
\end{tabular}

Table 6: Chi- Square statistics calculation table

\begin{tabular}{lcccc}
\hline $\mathrm{X}$ & $\mathrm{Oi}$ & $\mathrm{Ei}$ & $(\mathrm{Oi}-\mathrm{Ei})^{2}$ & $\left((\mathrm{Oi}-\mathrm{Ei})^{2}\right) / \mathrm{Ei}$ \\
\hline 1 & 0 & 47.20 & 300 & 0.063559322 \\
2 & 12 & 47.20 & 1239.04 & 26.25084746 \\
3 & 16 & 47.20 & 973.44 & 20.62372881 \\
4 & 14 & 47.20 & 1102.24 & 23.35254237 \\
5 & 194 & 47.20 & 21550.24 & 456.5728814 \\
\hline \multicolumn{7}{l}{ Total } & & & 526.8635593 \\
\hline
\end{tabular}

It follows that the size of a road can be appreciated given empirical value per unit time. Analyzing the aspect of road usage, number of registered vehicles (Number) and ownership (vehicles/No. of owners) were set as measurable indicators. For instance, when the number of registered vehicle is high, there is need for increased budgetary allocation to road asset maintenance since stress on road increases with number of vehicles on the road. Ownership (vehicles/No. of owners), presents an overview of the number of persons that jointly use a vehicle. It matches the number of vehicles on the road and the population in the catchment areas. In other fields, KPIs can be extracted and put to use. For instance, in the health sector, the Hon Minister may launch an appraisal of the performance of the prenatal programme in Nigeria. The key performance indicator in that case shall be increased rate of survival of mother with survival/pregnancy as unit of evaluation. 
Table 7: Templates formed by the researcher from literature review, field investigations and practice experience - $A$ three-year Key Performance Indicator (KPI) evaluation plan Key Performance Indicator (KPI)

\begin{tabular}{|c|c|c|c|c|c|c|}
\hline \multirow[b]{2}{*}{ Aspect } & \multirow[b]{2}{*}{ Indicator } & \multirow[b]{2}{*}{ Units } & \multirow[b]{2}{*}{$\begin{array}{l}\text { Current } \\
\text { Status }\end{array}$} & \multicolumn{3}{|c|}{ Target KPIs } \\
\hline & & & & $\begin{array}{l}\text { Next } \\
\text { year }\end{array}$ & $\begin{array}{l}\text { Next } \\
\text { two } \\
\text { years }\end{array}$ & $\begin{array}{l}\text { Next } \\
\text { three } \\
\text { years }\end{array}$ \\
\hline \multirow{6}{*}{ Road network size } & i. length & $\mathrm{Km}$ & & & & \\
\hline & ii. paved & $\mathrm{Km}$ & & & & \\
\hline & iii. bridges, culverts & Number & & & & \\
\hline & iv. tunnels & Number & & & & \\
\hline & v. inks & $\mathrm{Km}$ & & & & \\
\hline & vi. right-of-way area & Hectare & & & & \\
\hline Asset value & i. recorded replacement cost & A & & & & \\
\hline \multirow[b]{2}{*}{ Road usage } & i. registered vehicles & Number & & & & \\
\hline & ii. ownership & $\begin{array}{l}\text { Vehicles / No. of } \\
\text { Owners }\end{array}$ & & & & \\
\hline \multirow{4}{*}{$\begin{array}{l}\text { Demography } \\
\text { and macroeconomic } \\
\text { information }\end{array}$} & i. Population & Number & & & & \\
\hline & ii. total land area & $\mathrm{Km}^{2}$ & & & & \\
\hline & iii. urbanization & $\begin{array}{l}\% \text { of population in } \\
\text { urban area }\end{array}$ & & & & \\
\hline & $\begin{array}{l}\text { iv. Gross Domestic Product } \\
\text { (GDP) }\end{array}$ & A & & & & \\
\hline \multirow[t]{2}{*}{$\begin{array}{l}\text { Network } \\
\text { density and } \\
\text { availability }\end{array}$} & i. road density & $\begin{array}{l}\text { Road length } \\
(\mathrm{Km}) / \mathrm{Area} \text { using the } \\
\operatorname{road}\left(1,000 \mathrm{Km}^{2}\right)\end{array}$ & & & & \\
\hline & ii. road availability & $\mathrm{Km} / 10^{6}$ persons & & & & \\
\hline \multirow{2}{*}{ Utilization } & i. travel & Veh $x \mathrm{~km} / \mathrm{yr}$ & & & & \\
\hline & ii. goods & Tonne x km/yr & & & & \\
\hline \multirow{3}{*}{ Safety } & i. accidents & Number & & & & \\
\hline & ii. fatalities & Number & & & & \\
\hline & iii. injuries & Number & & & & \\
\hline \multirow{2}{*}{ User costs } & $\begin{array}{l}\text { i. vehicle } \\
\text { operating costs }\end{array}$ & Average $\mathrm{A} /$ Veh x km & & & & \\
\hline & $\begin{array}{l}\text { ii. travel time } \\
\text { costs }\end{array}$ & $\mathrm{A} /$ Veh $\mathrm{x} \mathrm{km}$ & & & & \\
\hline \multirow{3}{*}{$\begin{array}{l}\text { Operational } \\
\text { effectiveness }\end{array}$} & $\begin{array}{l}\text { i. incident } \\
\text { response time }\end{array}$ & Minutes & & & & \\
\hline & $\begin{array}{l}\text { ii. claims by road users for } \\
\text { potholes and other road } \\
\text { problems }\end{array}$ & A & & & & \\
\hline & $\begin{array}{l}\text { iii. injury response } \\
\text { time }\end{array}$ & Days & & & & \\
\hline Expenditure scheme & i. maintenance expenditures & $\mathrm{A} / \mathrm{km}^{2}$ & & & & \\
\hline Shortfall & i. Value of backlog work & $\%$ of budget & & & & \\
\hline Economic returns & i. Network depreciation & $\begin{array}{l}\text { \{(road value when new } \\
\text { - current value)/ road } \\
\text { value when new\}\% }\end{array}$ & & & & \\
\hline \multirow{3}{*}{ Cost recovery } & i. Revenues & A & & & & \\
\hline & ii. Revenues/expenditure Ratio & $\%$ & & & & \\
\hline & $\begin{array}{l}\text { iii. Revenue/maintenance } \\
\text { Expenditure ratio }\end{array}$ & $\%$ & & & & \\
\hline \multirow{2}{*}{$\begin{array}{l}\text { Research and } \\
\text { training }\end{array}$} & i. Expenditures & A & & & & \\
\hline & ii. Personnel trained & Number & & & & \\
\hline
\end{tabular}


Table 8: Table highlighting key PPP projects being undertaken in Nigeria

\begin{tabular}{|c|c|c|c|c|c|}
\hline S/No & Project/PPP Model & Contracting Authority & Private Partner & Size/Value & Status \\
\hline 1 & $\begin{array}{l}\text { Akamkpa Toll Road Project } \\
\text {-Cross River/BOT }\end{array}$ & $\begin{array}{l}\text { Cross River State } \\
\text { Government }\end{array}$ & $\begin{array}{l}\text { Daystar Akamkpa } \\
\text { Investment } \\
\text { Company Ltd }\end{array}$ & $45 \mathrm{~km}$ & $\begin{array}{l}\text { MOU signed } \\
\text { With Cross River } \\
\text { State Government }\end{array}$ \\
\hline 2 & Lekki Toll Road/BOT & $\begin{array}{l}\text { Lagos State Bridges } \\
\text { Roads \& Highway } \\
\text { Authority }\end{array}$ & $\begin{array}{l}\text { Lekki Concession } \\
\text { Company }\end{array}$ & N50Billion & $\begin{array}{l}\text { Financial close } \\
\text { achieved. }\end{array}$ \\
\hline 3 & $\begin{array}{l}\text { Lagos-lbadan Toll } \\
\text { Road/DBOT }\end{array}$ & $\begin{array}{l}\text { Federal Ministry of } \\
\text { Works }\end{array}$ & $\begin{array}{l}\text { Bi-Courtney Consor- } \\
\text { tium }\end{array}$ & $\begin{array}{l}105 \mathrm{~km} / \\
\text { N89Billion }\end{array}$ & $\begin{array}{l}\text { Project renego- } \\
\text { tiations. }\end{array}$ \\
\hline 4 & $\begin{array}{l}\text { Katampe District Infra- } \\
\text { structure/Design, Fi- } \\
\text { nance, Construct\& } \\
\text { Transfer }\end{array}$ & $\begin{array}{l}\text { Federal Capital } \\
\text { Development Agency } \\
\text { Nigeria }\end{array}$ & $\begin{array}{l}\text { Deans hanger Project } \\
\text { Ltd }\end{array}$ & N61Billion & $\begin{array}{l}\text { Financial close } \\
\text { achieved. }\end{array}$ \\
\hline 5 & $\begin{array}{l}\text { Teragro Benfruit Plant/ } \\
\text { Lease }\end{array}$ & $\begin{array}{l}\text { Benue State } \\
\text { Government }\end{array}$ & $\begin{array}{l}\text { Transnational Corpo- } \\
\text { ration of Nigeria }\end{array}$ & $\begin{array}{l}26,500 \text { metric } \\
\text { toncapacity } \\
\text { plant }\end{array}$ & $\begin{array}{l}\text { Project Agreements } \\
\text { Executed; Operations } \\
\text { commenced. }\end{array}$ \\
\hline 6 & $\begin{array}{l}\text { Tinapa Free Trade Zone } \\
\text { /Concession }\end{array}$ & $\begin{array}{l}\text { Cross River State } \\
\text { Government }\end{array}$ & $\begin{array}{l}\text { Tinapa Business Re- } \\
\text { sort Limited }\end{array}$ & 265hectares & $\begin{array}{l}\text { Operations } \\
\text { stage }\end{array}$ \\
\hline 7 & $\begin{array}{l}\text { Akwalbom Agro- } \\
\text { Industries Ltd/ } \\
\text { Concession }\end{array}$ & $\begin{array}{l}\text { Akwa Ibom } \\
\text { Investment and } \\
\text { Promotion Council } \\
\text { (AKIIPOC) }\end{array}$ & $\begin{array}{l}\text { Southern Investment } \\
\text { Ltd }\end{array}$ & $\begin{array}{l}\text { Estimated at } \\
\$ 38 \text { million }\end{array}$ & $\begin{array}{l}\text { Feasibility study } \\
\text { completed. }\end{array}$ \\
\hline 8 & $\begin{array}{l}\text { Greater Port Harcourt } \\
\text { Housing Scheme }\end{array}$ & $\begin{array}{l}\text { Greater Port Harcourt } \\
\text { City Development } \\
\text { Authority (GPHCDA) }\end{array}$ & DSC International & $\begin{array}{l}\text { Estimated at } \\
\text { N25billionplus } \\
\text { N9.5billionfor } \\
\text { Internal Town- } \\
\text { ship Services. }\end{array}$ & $\begin{array}{l}\text { Construction } \\
\text { stage. }\end{array}$ \\
\hline 9 & $\begin{array}{l}\text { Lagos Urban Light Rail } \\
\text { Project/BOT }\end{array}$ & $\begin{array}{l}\text { Lagos Area Metropolitan } \\
\text { Transport Authority }\end{array}$ & Eko Rail Limited & \$550Million & $\begin{array}{l}\text { Contract negotiation } \\
\text { stage }\end{array}$ \\
\hline 10 & $\begin{array}{l}\text { MMII Airport Project/ } \\
\text { DBOT }\end{array}$ & $\begin{array}{l}\text { Federal Airways } \\
\text { Authority of Nigeria }\end{array}$ & $\begin{array}{l}\text { Bi-Courtney Aviation } \\
\text { Services Limited }\end{array}$ & N34Billion & $\begin{array}{l}\text { Construction } \\
\text { completed; } \\
\text { Operations stage }\end{array}$ \\
\hline
\end{tabular}

(Source: Infrastructure Concession Regulatory Commission, ICRC, 2017)

\subsection{Challenges to Effective Utilization of KPIs}

The major issue hindering effective utilization of KPIs hinges on appreciation of the principles. A performance indicator that is not measurable is deemed unpopular. Appreciation of the principles means ability to issue an acceptable unit for measuring specific performance. A maize farmer who uses a bag of fertilizer per year under controlled circumstances could adopt Tons/bag as unit of measuring the performance of a given fertilizer. In that situation, 1 Tons/bag means that 1 bag of fertilizer supported a yield of 1 Ton of maize for the given year. Given the same farm condition the type of fertilizer could be varied to ascertain the impact of fertilizer type on maize yield. To overcome under application of measurable indicators, awareness has to be created on the need to work with only measurable indicators in Ministries, Departments and Agencies (MDAs) of government. Relevant trainings should equally be approved to enhance knowledge of extracting units of measurements from general concepts.

\subsection{Highlight of key PPP Projects Being Undertaken in Nigeria}

Table 8 focuses on PPPs on a larger scale and in the more conventional use of the term, highlighting the key PPP projects being undertaken in Nigeria. It is expected that this number would increase reasonably over the coming years with increased acceptability PPP funding option.

\section{CONCLUSIONS AND RECOMMENDATION}

\subsection{Conclusions}

Based on findings from the study, it can be concluded that there are several key performance indicators that will improve performance of PPP projects in Nigeria. 
Stakeholders had very good agreements on their rankings of the key performance indicators in PPP projects. That was depicted by high values of standard deviation. They perceive that increased road network was the most relevant of these key performance indicators on PPP projects. In this research, a considerable insight into the evolution and application of performance measurement for PPP projects was made. Trends toward the application of performancebased management systems were found in many sectors, especially transportation. PPP agreements showed trends in how agencies' performance measures and KPIs are exposed to flexibility in changes that occur over the term of projects.

\subsection{Recommendations}

i. Consider asset management plans during procurement and concession agreement negotiation to avoid confusion when retainer ship term expires.

ii. There is need for basic KPI template, which shall represent a consolidation of international best practice for the roads sector. Such document should command popular acceptance.

iii. Focus on customer needs and societal goals in addition to asset condition. Performance indicators should be linked to policy objectives to implement targets or minimum acceptable levels of performance giving relevance to the views of the end-users.

iv. Do not rely completely on KPIs to align agency goals and project performance, but strive to create an asset management culture through asset management plans that are continuously improved throughout the concession period.

v. Focus on measures and indicators that result in both outcomes and data outputs to boost records and future evaluation of PPP projects.

\section{REFERENCES}

[1] Li, B., Akintoye, A., Edwards, P. J., and Hardcastle, C. Perceptions of positive and negative factors influencing the attractiveness of PPP/PFI Procurement for Construction projects in the UK, findings from a questionnaire survey, Engineering, Construction and Architectural Management, 12(2), 125-148. 2005.

[2] Farrah, T. "Brumby wins battle to keep East Link costs secret" The Age, February 14, 2007.

[3] Zhang, X. Q. Paving the Way for Public-Private Partnerships in Infrastructure Development, Journal of Construction Engineering and Management, 131(1), 71-80, 2005.
[4] Thuen, F., and LÆRUM, K. T. A Public/Private Partnership in Offering Relationship Education to the Norwegian Population, Family Process, 44(2), 175-185, 2005.

[5] Koppenjan, J. F. M. The Formation of PublicPrivate Partnerships: Lessons from Nine. Transportation Infrastructure Projects in the Netherlands, Public Administration, 83(1), 13515,2005 .

[6] Spackman, M. Public-private partnerships: lessons from the British approach, Economic Systems, 26, 283-301, 2002.

[7] Askar, M. M., and Gab-Allah, A. A. Problems Facing Parties Involved in Build, Operate, and Transport Projects in Egypt, Journal of Management in Engineering, 18(4), 173-178. 2002.

[8] Badshah, A. Good Governance for Environmental Sustainability, Public Private Partnerships for the Urban Environment Programme (PPPUE), United Nations Development Program, UNDP, New York,1998.

[9] Tiong, R. L. K. Comparative Study of BOT Projects, Journal of Management in Engineering, 6(1), 107122, 1990.

[10] Boase, J. P. Beyond Government? The Appeal of Public-Private Partnerships, Canadian Public Administration, 43(1), 75-92. 2000.

[11] Abdul-Aziz, A. Unraveling of BOT Scheme: Malaysia's INDAH Water Konsortium, Journal of Construction Engineering and Management, 127 (6), 457-460. 2001.

[12] Bloomfield, P. The Challenging Business of LongTerm Public-Private Partnerships: Reflections on Local Experience, Public Administration Review, March | April, 400-411, 2006.

[13] Akintoye, A., Hardcastle, C., Beck, M., Chinyio, E., and Darinka Asenova, D. Achieving best value in private finance initiative project procurement, Construction Management and Economics, 21, 461-470, 2003.

[14] Alonso-Conde, A. B., Brown, C., and Rojo-Suarez, J. Public private partnerships: Incentives, risk transfer and real options, Review of Financial Economics, 2007.

[15] Kumaraswamy, M. M., and Anvuur, A. M. Selecting sustainable teams for PPP projects. Building and Environment, 43(6), 999-1009, 2008.

[16] Kumaraswamy, M. M., and Morris, D. A. BuildOperate-Transfer-Type Procurement in Asian Megaprojects, Journal of Construction Engineering and Management, 128(2), 93102, 2002.

[19] Lo, W., Chao, C. H., Hadavi, A., and Krizek R. J. Contractor Selection Process for Taipei Mass Rapid Transit System, Journal of Construction Engineering and Management, 14(3), 57-65, 1997.

[20] Tiong, R. L. K. Risks and Guarantee in BOT Tender, Journal of Construction Engineering and Management, 21(2), 183-188, 1994. 
[21] Wang, S. Q., Tiong, R. L. K., Ting, S. K., and Ashley, D. Political Risks: Analysis of Key Contract Clauses in China's BOT Project, Journal of Construction Engineering and Management, 125, (3), 190-197, 1999.

[22] Zhang, X. Q. Criteria for Selecting the PrivateSector Partner in Public-Private Partnerships, Journal of Construction Engineering and Management, 131(6), 631-644. 2005.

[24] Qiao, L., Wang, S. Q., Tiong, R. L. K., and Chan, T. S. Framework for critical success factors of BOT projects in China, Journal of Project Finance, 7(1), 53-61. 2001.

[25] Li, Q. M. "Critical Success Factor for PPP Projects in the UK Construction Industry", Construction Management and Economics, Vol. 23, p. 50, 2006.

[25] Noble, G., and Jones, R. The Role of Boundaryspanning Managers in the Establishment of Partnerships, Public Administration, 84(4), 89191, 2006.

[26] Kagioglou, M., Cooper, R., and Aouad, G. Performance management in construction: a conceptual framework. Construction Management and Economics, 19 pp. 85-95, 2001.

[27] Bititchi, U.M., Carrie, A.S., and McDevitt, L. Integrated performance measurement systems: an audit and development guide, The TQM Magazine, 9(1), 46-53, 1997.

[28] Wall, Anthony and Gary Martin. The Disclosure of Key Performance Indicators in the Public Sector: How Irish Organizations are Performing. Public Management Review, 5(4), December. 2003

[29] Pallister, J. and Isaacs, A. ed. A Dictionary of Business. 2nd edition. Oxford: OUP, 1996.

[30] Cox, R.F., Issa, R. R. A., Ahrens, D. Management's perception of key performance indicators for construction. Journal of Construction Engineering and Management, 129 (2), 142-151, 2003.

[31] Australian National Audit Office, "Performance Information Principles, Better Practice Guide", Australian Government Printing Service, 1996.

[32] Grimsey, D., Lewis, M. K., Public Private Partnerships: The Worldwide Revolution in Infrastructure Provision and Project Finance, Edward Elgar Publishing, Cheltenham, UK. 2004.

[33] Burney, L. L., Swanson, N. J., "The Relationship between Balanced Scorecard Characteristics and Managers' Job Satisfaction", Journal of Managerial Issues, Vol. 22 No. 2, pp. 166-181, 2010.

[34] Atkinson, A.A., and Waterhouse, J.H., Wells, R. B., "A Stakeholder Approach to Strategic Performance Measurement", Spring, Sloan Management Review, 38 (3), 25-37, 1997.

[35] Behn, R. D. "Why Measure Performance? Different Purposes Require Different Measures", Public
Administration Review, Vol. 63 No. 5, pp. 586-606, 2003.

[36] Partnerships Victoria, Overview: Guidance Material - July 2006", Victorian Government Printing Office, 2006a.

[37] Partnerships Victoria, "Partnerships Victoria", Victorian Government Printing Office. 2006b.

[38] Lee, J., Fisher, G., "The Perceived Usefulness and Use of Performance Information in the Australian Public Sector", Accounting, Accountability and Performance, Vol.13 No. 1, pp. 42-73, 2007.

[39] Evans, P., Bellamy, S., "Performance evaluation in the Australian public sector: The role of management and cost accounting control systems", International Journal of Public Sector Management, Vol. 8 No. 6, pp. 30-38, 1995.

[40] Edwards, P., Shaoul, J., Stafford, A., Arblaster, L., "Evaluating the operation of PFI in roads and hospitals", Research Report No. 84, The Association of Chartered Certified Accountants, 2004.

[41] Cambridge Economic Policy Associates, , "Public Private Partnerships in Scotland: Evaluation of Performance", Final Report, Cambridge Economic Policy Associates Ltd, 2005.

[42] Javed, A. A., Lam, P. T. I., and Zou, P. X. W., “Outputbased specifications for PPP projects: lessons for facilities management from Australia", Journal of Facilities Management, Vol. 11 No. 1, pp. 5-30, 2013.

[43] Mandri-Perrott, C., "Private Sector Participation in Light Rail-Light Metro Transit Initiatives", PublicPrivate Infrastructure Advisory Facility, The World Bank, 2010.

[44] Aibinu, A. and Odeyinka H. A. Construction delays and their causative factors in Nigeria, Journal of Construction Engineering and Management, 132 (7), 667677.2006.

[46] Siegel, S. and N. John C., Jr. Nonparametric Statistics for the Behavioral Sciences, 2nd edition, McGraw-Hill, New York. 1988.

[46] The Canadian Council for Public-Private Partnerships Report. "Anthony Henday Drive Southeast Leg Rind Road, Edmonton, Alberta." In 2005 National Awards Celebrating Innovation and Excellence. Toronto: Author, , pp. 67-83, 2006.

[48] Zhang X. Q., Kumaraswamy M. M., Zheng W., and Palaneeswaran E. Concessionaire Selection for Build-Operate-Transfer Tunnel Projects in Hong Kong, Journal of Construction Engineering and Management, 128 (2), 155-163. 2002.

[49] Tiong, R. L. K., Yeo, K., and McCarthy, S. C. Critical Success Factors in Winning BOT Projects, Journal of Construction Engineering and Management, 18(2), 217-228, 1992 